\title{
Crucifixos invisíveis: polêmicas recentes no Brasil sobre símbolos religiosos em recintos estatais
}

\section{Emerson Giumbelli}

\section{(2) OpenEdition \\ 12 Journals}

Edição electrónica

URL: http://journals.openedition.org/aa/1019

DOI: $10.4000 /$ aa. 1019

ISSN: 2357-738X

Editora

Programa de Pós-Graduação em Antropologia Social (UnB)

\section{Edição impressa}

Data de publição: 1 dezembro 2011

Paginação: 77-105

ISSN: 0102-4302

\section{Refêrencia eletrónica}

Emerson Giumbelli, «Crucifixos invisíveis: polêmicas recentes no Brasil sobre símbolos religiosos em recintos estatais», Anuário Antropológico [Online], v.36 n. 1 | 2011, posto online no dia 10 novembro 2015, consultado o 28 abril 2021. URL: http://journals.openedition.org/aa/1019; DOI: https://doi.org/ 10.4000/aa. 1019

\section{(c) (i) $९$}

Anuário Antropológico is licensed under a Creative Commons Atribuição-Uso Não-Comercial-Proibição de realização de Obras Derivadas 4.0 International. 


\section{Crucifixos invisíveis: polêmicas recentes no Brasil sobre símbolos religiosos em recintos estatais*}

Emerson Giumbelli

Departamento de Antropologia/UFRGS

\section{Introdução}

Dia $1^{\circ}$ de janeiro de 2011, data da posse da primeira presidente da República Federativa do Brasil, Dilma Rousseff. Um dos momentos que integram o ritual da posse, em uma sessão do Congresso Nacional, é o do juramento e do discurso da candidata eleita, durante o qual se dá a proclamação do sucessor ao cargo mais importante da política institucionalizada. Essa sessão ocorre no plenário da Câmara dos Deputados. O ritual prossegue ao ar livre, diante do Palácio que abriga o gabinete da Presidência, quando há o encontro com o agora ex-presidente e ocorre outro discurso, desta vez dirigido ao "povo" que se manifesta em praça pública. Dos inúmeros símbolos que atravessam o ritual na sua totalidade, chamo a atenção para um que se faz presente no plenário da Câmara dos Deputados. Em vídeos e fotos, Dilma pode ser vista discursando em um púlpito adornado com o brasão da República; mas não é este o símbolo que me interessa destacar, e sim outro, que aparece às costas da presidente: um crucifixo [Foto1]. Se nessa ocasião o objeto pareceu não ter despertado comentários, a situação serve para indicar o tema deste texto, dedicado a polêmicas recentes sobre a legitimidade da presença de cruzes e crucifixos em recintos estatais. Procuro expor adiante alguns resultados de pesquisas que insistem no tema da relação entre religião e espaço público (Birman, 2003), mas com aportes renovados pela incorporação de referências que me parecem relevantes. ${ }^{1}$

A história do Brasil republicano registra várias ocorrências de protestos contra a presença de "símbolos religiosos" em tribunais, parlamentos e órgãos públicos. Eu mesmo me dediquei a analisar uma dessas situações, que se passou em 1891, na então capital nacional (Giumbelli, 2003). No período recente, é possível localizar uma cadeia de casos que apontam como gênese a situação ocorrida em 2005, no Rio Grande do Sul. Naquela ocasião, um juiz propôs, em um congresso estadual de magistrados, uma moção que sugeria a retirada do crucifixo e de outros símbolos religiosos das salas de audiência de tribunais gaúchos. A moção saiu perdedora, mas teve repercussão ampla. Em 2007, instrumentos legais foram apresentados ao Conselho Nacional de Justiça (CNJ) em favor da retirada de crucifixos que existiam em 
quatro tribunais e provocaram uma decisão que se pronuncia geralmente sobre a presença desses objetos.
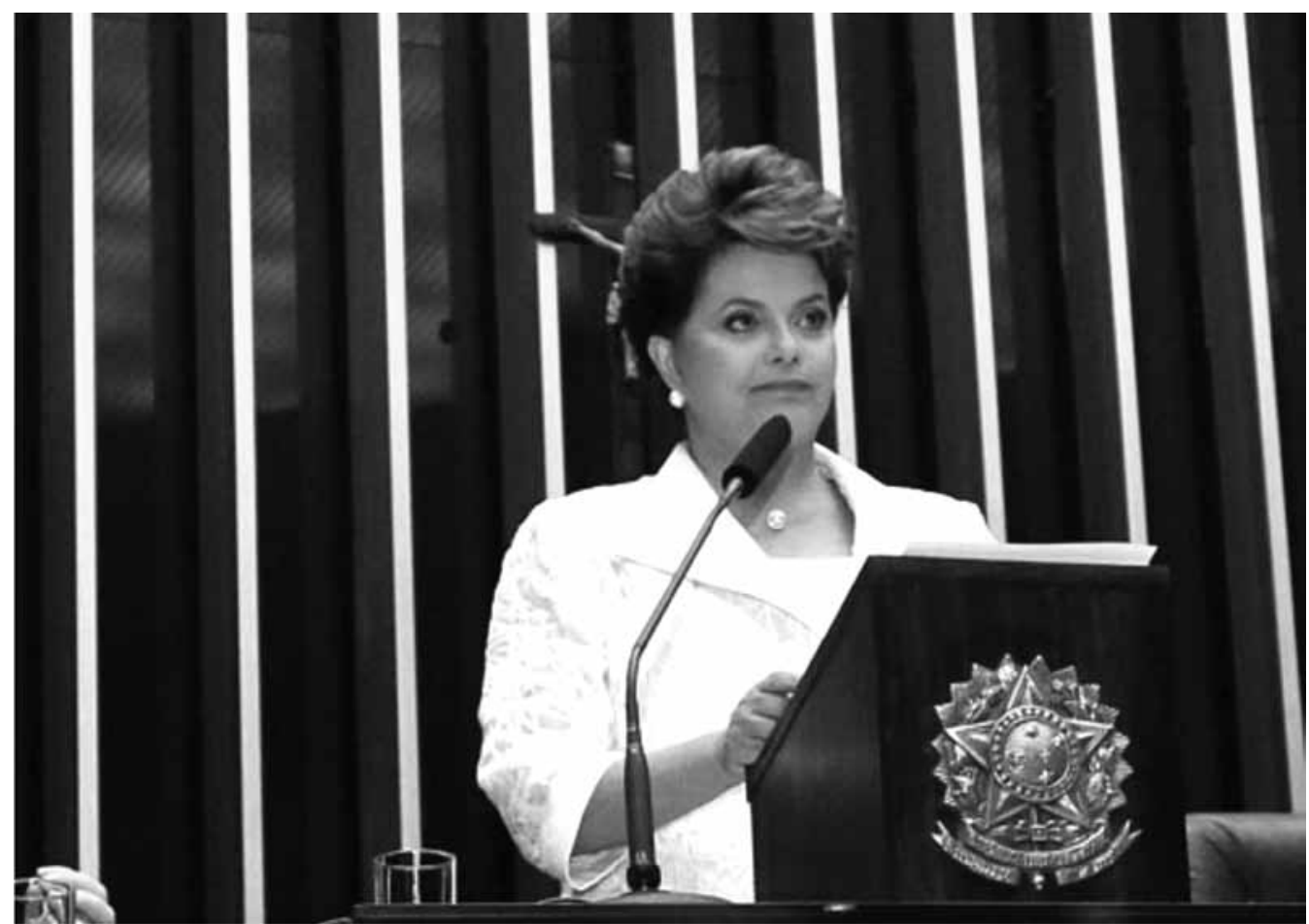

Dilma Rousseff durante cerimônia de posse como presidente da República na Câmara dos Deputados, Brasília, 01/01/2011

Fonte: http://www.cartacapital.com.br/politica/dilma-toma-posse-sou-a-presidentade-todos-os-brasileiros. Acessado em 15/02/2011 - http://blogdocorretor.com/?cat=10

Em 2009, um representante do Ministério Público Federal, em São Paulo, ajuizou uma Ação Civil Pública requerendo que a União removesse, nas repartições públicas federais paulistas, "dos locais de ampla visibilidade, e de atendimento ao público, os símbolos de qualquer religião”. A decisão de uma vara cível federal de São Paulo, em caráter liminar, rejeitou os fundamentos desta Ação. No mesmo ano, o Ministério Público do Piauí tomou iniciativas no sentido de encaminhar representação, subscrita por várias organizações da sociedade civil, solicitando que "os dirigentes dos órgãos públicos sejam instados a retirar destes qualquer emblema identificador de determinada religião ou seita”. Ainda em 2009, o mesmo tema constou de um documento divulgado pelo governo federal, a terceira edição do Plano Nacional de Direitos Humanos. Uma das ações previa "desenvolver mecanismos para impedir a ostentação de símbolos religiosos em estabelecimentos 
públicos da União”. Esta foi uma das duas ações suprimidas na versão revista do documento, divulgada em 2010. ${ }^{2}$

Considerando esse conjunto de situações recentes, sistematizei e localizei artigos em jornais de ampla circulação e em sites jurídicos, os quais se posicionavam contra ou a favor da presença de símbolos religiosos em estabelecimentos públicos. Privilegiei, como regra, as fontes mais públicas - desde documentos oficiais a textos de ampla circulação - e mais articuladas - na medida em que permitem acompanhar o argumento que desenvolvem. Um texto publicado em livro foi agregado, por se dedicar especificamente ao assunto. As fontes se distribuem entre os anos de 2005 e $2010 .^{3}$ Não é de meu interesse elucidar quaisquer dessas situações, esclarecendo as motivações de seu surgimento ou as razões de seu desfecho. Também deixei de abordar as características sociológicas dos seus participantes, partindo da constatação de que não se trata - ou não se trata apenas - de um embate entre grupos delimitados. Meu foco recai basicamente sobre os argumentos acionados em controvérsias públicas. A opção é favorecida pelo fato de que o embate tenha se restringido aos textos, sem qualquer registro de retirada dos objetos em torno dos quais se dão os casos mencionados. Por outro lado, pode-se constatar que os argumentos não estão vinculados a esse ou àquele episódio específico. Sua recorrência permite abordá-los de maneira relativamente independente. Como estratégia de apresentação, privilegio as situações do CNJ e do Ministério Público paulista, pela sua importância no cenário nacional.

\section{Casos bons para começar}

Apesar de nomes próprios serem secundários neste texto, há alguns incontornáveis, e entre eles está o de Daniel Sottomaior. Ele é o autor dos "pedidos de providência” dirigidos ao CNJ e está na origem do procedimento administrativo que levou à instauração da ACP pelo Ministério Público Federal em São Paulo. O texto da Ação cita "representação" oferecida por Sottomaior depois que se sentiu ofendido com a presença de um crucifixo na sede do Tribunal Regional Eleitoral de São Paulo. Um modelo de representação pode ser encontrado no site "Brasil para Todos", que se apresenta como uma "campanha" iniciada em 2007 em prol da "democratização dos espaços e dos serviços públicos brasileiros”. ${ }^{4}$ Sottomaior é o promotor da campanha, que arregimenta apoios individuais (entre eles, o do juiz que propôs a moção de 2005 no Rio Grande do Sul) e institucionais. O site informa que vários parlamentos e tribunais já foram interpelados. Além disso, a campanha, através de seu site, incentiva qualquer cidadão a reivindicar a retirada de símbolos religiosos de estabelecimentos públicos e, por esta razão, oferece um modelo de representação. Conside- 
rando que não tive acesso aos textos dos “pedidos de providência” encaminhados ao CNJ, tomo este modelo como ponto de partida da análise.

Nesse modelo, imagina-se a situação de um cidadão que tenha comparecido a determinado tribunal e lá tenha visto "um crucifixo afixado no plenário (fotografia anexa)". Segue-se denúncia a "uma forma de manifestação religiosa que ofende o princípio da laicidade estatal, materializado no artigo 19, inciso I, da Constituição Federal”. Instaurado desde o início do regime republicano, este princípio é desrespeitado por agentes políticos e servidores públicos que "utilizam o patrimônio estatal para divulgar crenças religiosas, mediante a exibição de símbolos, textos e imagens que as identificam”. A presença de símbolos religiosos, continua a denúncia, sugere que os servidores estariam "submetidos a outros princípios que não aqueles que regem a administração pública no Brasil" e é condenável pelo "constrangimento que desperta nos cidadãos que professam diferentes filosofias de vida". O texto ainda cita outras ocorrências da polêmica e dois trechos de um livro sobre laicidade, no qual este princípio se vincula à neutralidade estatal, sendo condenada a presença dos símbolos religiosos e de objetos "apostos em mesas de trabalho" e "palavras impressas em expressões oficiais". O signatário hipotético é "João da Silva".

A petição que estabeleceu a Ação Pública em $2009^{5}$ começa exatamente invocando a ofensa acusada por Sottomaior e fazendo menção a uma foto do Tribunal Regional Eleitoral de São Paulo. Expondo estatísticas do IBGE que mostram a diversidade de opções religiosas no Brasil, o texto continua notando que, nas repartições públicas, pessoas "se deparam com símbolos (v.g. crucifixo) religiosos que não pertencem às suas religiões, fato este que atenta contra a liberdade de crença dos cidadãos que procuram o serviço público, e demonstra que o Estado estabelece preferências entre credos e crenças" (:2-3). Uma série de normas é invocada a propósito da liberdade de crença, desde a Declaração Universal e outros documentos da ONU, passando pela Constituição Federal, até uma lei que pune, entre outras, a discriminação religiosa. Isto, porém, é contrabalançado pelo princípio da laicidade, fundamentado no artigo 19 da Constituição Federal.

O resultado é a exigência de que os servidores públicos não ostentem suas crenças religiosas quando estiverem a serviço do Estado. Neste papel, têm o dever de preservar a neutralidade em relação às diferentes concepções religiosas presentes na sociedade. A fim de proteger todas as religiões, o Estado não pode dar preeminência a uma, representada por símbolos apostos em prédios públicos. O documento termina lembrando princípios comprometidos com a isonomia do serviço público e destacando a importância da questão quando o Poder Judiciário intervém em temas com dimensões políticas, morais e religiosas, a exemplo da legalidade de pesquisas com células-tronco. 
Vejamos agora o parecer em que o $\mathrm{CNJ}$ se baseou no sentido de deixar a critério de cada juiz a manutenção ou não do crucifixo em salas dos tribunais. O parecer, na verdade, acumula razões para a manutenção do objeto. ${ }^{6}$ Sem discordar de que no Brasil o Estado é laico, aponta que não há no ordenamento jurídico brasileiro, incluindo o artigo 19 da Constituição Federal, proibição expressa para o uso de qualquer símbolo religioso. $\mathrm{O}$ fato de este símbolo ser um crucifixo explica-se pela tradição, ou pela cultura cristã brasileira. Diz o parecer: "A cultura e a tradição [...] inseridas numa sociedade oferecem aos cidadãos em geral a exposição permanente de símbolos representativos, com os quais convivemos pacificamente [...]". Trata-se de interesses individuais "inseridos, pela cultura, no direito coletivo" e que não violam outros interesses ou direitos individuais. Continua o documento: "A exposição de tal símbolo não ofende o interesse público primário (a sociedade); ao contrário, preserva-o, garantindo interesses individuais culturalmente solidificados e amparados na ordem constitucional, como é o caso deste costume, que representa as tradições de nossa sociedade”. Concorda que não se pode permitir coação de consciência, mas sem "ignorar a manifestação cultural da religião nas tradições brasileiras, que hoje não representa qualquer submissão ao Poder clerical”. Além disso, o costume dos crucifixos é "uma representação, ainda que religiosa, do respeito devido ao local da Justiça”; é um símbolo que "homenageia princípios éticos e representa, especialmente, a paz”.

Por fim, a decisão da Justiça Federal em 2009, ${ }^{7}$ mais sucinta e já incorporando o parecer acima, declara que o Estado laico não é antirreligioso, mas o garantidor da liberdade religiosa. Vinculada à sociedade, "a laicidade não pode se expressar na eliminação dos símbolos religiosos, mas na tolerância aos mesmos”. Continua:

Em um país que teve formação histórico-cultural cristã é natural a presença de símbolos religiosos em espaços públicos, sem qualquer ofensa à liberdade de crença $[\ldots]$, eis que para os agnósticos ou que professam crença diferenciada, aquele símbolo nada representa, assemelhando-se a um quadro ou escultura, adereços decorativos.

Procurando infirmar a tese de que o objeto interfere nas decisões do Judiciário, defende a imparcialidade do julgador, mencionando como exemplo a discussão sobre aborto em casos de anencefalia. Conclui reproduzindo a expressão que consta no Preâmbulo da Constituição Federal: "Desta forma, o legislador constituinte, invocando a proteção de Deus [...], demonstrou profundo respeito ao Justo para conceber a sociedade justa e solidária a que se propôs”. 


\section{Laicidade e (contra)cultura}

Vê-se, desde logo, que há recorrência tanto quanto diversidade de pontos nessas argumentações. Um deles afigura-se como central, que é o da laicidade. A discussão sobre os crucifixos parece acentuar a polissemia da noção, pois, como se nota, a defesa da permanência do objeto não é acompanhada de um ataque à laicidade. Isto, porém, não significa que o tema não permaneça relevante e polêmico. ${ }^{8}$ O trabalho a fazer, portanto, é acompanhar as formas pelas quais se entende a laicidade, e também como se lida discursivamente com ela. Meu propósito, no que vem a seguir, é desdobrar a análise dos argumentos, partindo do tema da laicidade, em vários tópicos. Se o tema da laicidade é central, gostaria de mostrar que seu tratamento está articulado a outras dimensões, para cuja caracterização busco inspiração em noções ausentes nos próprios pronunciamentos, mas capazes de captar adequadamente seus sentidos e suas interações. Antes de tratar diretamente da laicidade, faço uma breve observação sobre a expressão "símbolos religiosos" tal como aparece no debate.

Algo notável, de fato, são a recorrência e a estabilidade que a expressão "símbolos religiosos" adquire no debate. Afinal, ela é aceita e acionada por todas as posições em jogo. Poderíamos dizer, numa fantasia antropológica, que todos leram Geertz (1989) quando este fala, em "A religião como sistema cultural”, chegando a mencionar a cruz como um exemplo, que um símbolo é "qualquer objeto, ato, acontecimento, qualidade ou relação que serve como vínculo a uma concepção - a concepção é o ‘significado' do símbolo” (:105). Também no debate que acompanhamos, a discussão se transfere do objeto para as concepções que ele suporta. Quase sempre nada se sabe sobre a biografia dos crucifixos, ou sobre os autores dos artefatos. Mesmo que algumas situações envolvam, na sua origem ou no seu fulcro, um determinado lugar, nunca o foco se dirige ao objeto que lá se situa. ${ }^{9}$ Os crucifixos em questão são sempre imaginários, embora existam bem materialmente. Designá-los como "símbolos religiosos" não significa, porém, que haja concordância a respeito de como tal símbolo funciona e acerca de que modo e até que ponto ele é religioso. Logo veremos isto. De toda maneira, tratar os crucifixos com esta expressão permite inseri-los em uma discussão mais ampla, de que participariam outros objetos e outras situações de diferentes religiões, e é exatamente isto que os credencia a se envolverem com a laicidade, ${ }^{10}$ pois, seja o que for que isto queira dizer, não há como definir a laicidade sem considerar o "religioso" (Asad, 2003).

Para tratar da laicidade do ponto de vista daqueles que demandam a retirada dos símbolos religiosos, podemos sintetizar o pensamento de Pinheiro (2007), que diversas vezes se expressou na polêmica. Diferentemente da petição da Ação Pública, sua argumentação preserva o ponto de partida, que é a defesa da liberdade 
religiosa, e termina qualificando a laicidade em termos de um regime de separação Estado-igreja que atinja todas as suas consequências. Vejamos: "muito embora a não confessionalidade estatal se qualifique como condição à existência de um real regime de separação, este não se esgota na natureza laica do Estado, impondo, para além disso, sua total neutralidade axiológica em matéria de fé [...]”. Continuando:

Isso significa, portanto, que, num regime de separação, além de ser vedado aos Estados professar uma específica doutrina religiosa (tal como ocorre nos Estados confessionais), também lhe é obstado conferir tratamento diferenciado a qualquer crença (seja para favorecer, seja para prejudicá-la) e enviar, através de seus comportamentos, sinais aos seus cidadãos no sentido de uma identificação estatal com determinado pensamento religioso. Até porque, enfatize-se, qualquer comportamento do Estado capaz de transmitir aos indivíduos, mesmo que sutilmente, uma tal mensagem de identificação e preferência em referência a determinada religião, traz, ainda, um outro recado, consistente, este sim, num juízo de demérito e de exclusão, no que concerne a todos aqueles cidadãos filiados às convicções religiosas preteridas, que, geralmente, são aquelas crenças minoritárias.

Constitui-se, assim, um contraponto entre identificação e neutralidade. É recorrente essa ideia de neutralidade como definição da laicidade. Outros exemplos entre os defensores da retirada de símbolos religiosos são Sarmento (2008), Livianu (2009), Farias (2010) e Roesler (2010). Sottomaior (2009) também pode ser citado: "Se não há religião oficial, também não pode haver religião 'não oficial mas preferida', o que daria no mesmo. Como as repartições no Estado laico irão exibir exatamente os mesmos símbolos religiosos que exibiam quando o regime era confessional?”. Finalmente, vale ainda transcrever o argumento de Vechiatti (2008):

há em nossa Constituição base jurídica suficiente para a restrição da exteriorização da liberdade religiosa em órgãos estatais: o princípio do Estado Laico (art. 19, inc. I da $\mathrm{CF} / 88$ ), que veda relações de aliança ou dependência entre o Estado e qualquer religião, ao passo que a ostentação de símbolos religiosos em órgãos estatais implica inequívoca relação de aliança com a religião em questão. Ademais, há um interesse público relevante na neutralidade confessional do Estado: garantir que as pessoas não sejam incomodadas com a religião alheia em órgãos estatais, evitando, assim, situações de enfrentamentos religiosos nos mesmos, na medida em que aqueles que são adeptos das religiões muitas vezes se sentem profundamente incomodados de ter que ficar frente a frente com símbolos de outras crenças religiosas, donde o Estado não deve adornar-se de símbolos religiosos em seus órgãos. 
O argumento de Vechiatti explicita qual é a intenção dos defensores da retirada dos crucifixos, que vinculam a ausência de símbolos religiosos ao item da Constituição Federal o qual, na opinião de muitos, traduziria o princípio da laicidade no ordenamento jurídico brasileiro. É esse vínculo que não é aceito pelos defensores da permanência do crucifixo. Alega-se, em primeiro lugar, como faz o parecer do conselheiro do CNJ, a inexistência de norma que expressamente exija a ausência de símbolos religiosos em repartições públicas. $\mathrm{O}$ argumento articula-se a um entendimento mais geral sobre a Constituição Federal: “[...] a CF, em seu art. 19, I, prevê até mesmo a possibilidade de aliança entre Estado e Igreja sempre que, nos termos da lei, houver interesse público. Um Estado não confessional significa apenas não regrado por normas religiosas, sem implicar nenhuma postura comissiva de hostilidade ao status quo" (Capez, 2009; ver tb. Sales, 2009 e sua ênfase na ideia de cooperação entre Estado e religiões). Sobretudo, encontra-se um fundamento para a sua presença em fatores que remetem a noções como "tradição", "história", "cultura", "sociedade", conforme já notamos nas decisões dos dois casos com os quais se iniciou a exposição.

Vejamos outros exemplos. Para Nalini (2005), "a separação entre igreja e Estado não significa o banimento de toda a simbologia que integra o caráter brasileiro”. Lembra que a "nação brasileira nasceu sob a invocação da cruz" e menciona fatos da história colonial a partir dos quais devemos entender porque "uma fé passou a integrar o ethos nacional", resultando na "profunda inserção de nossa cultura na chamada civilização cristã”. Segundo Kujawski (2007):

O Estado brasileiro é laico e está separado da Igreja. Sim, mas entre Estado e Igreja persiste, ainda e sempre, o vínculo social e cultural da religiosidade católica vigente entre nós durante cinco séculos. [...] A religião coletiva é um fenômeno histórico de longa duração, um uso arraigado no corpo social, impregnando as pessoas e as instituições de forma duradoura e persistente, um nexo social que não pode ser extirpado por lei nem por decreto. Do ponto de vista jurídico, separação não é o mesmo que divórcio.

Eis agora o argumento de um expoente eclesiástico (Tempesta, 2010):

Um país laico é aquele que respeita todas as religiões e sabe acolher a cultura de seu povo. [...] A cultura cristã e católica integra a história de nosso país. [...] Trata-se, antes de tudo, de uma questão de preservação da memória de nossa história e das raízes culturais da nossa identidade brasileira. Querer coibir a ostentação dos símbolos da cultura que berçou e construiu a nossa história é, isto sim, um verdadeiro sinal de intolerância. 
Martins (2009a), Douglas (2009) e Costa (2009) levantam igualmente o argumento que invoca a tradição como razão da presença e da permanência do crucifixo. Entre os defensores, é comum a lembrança, como fez a decisão em 2009 no caso da Ação Pública, de que o Preâmbulo da Constituição Federal menciona a "proteção de Deus". Um exemplo, entre os mais contundentes:

O pedido de retirada dos objetos partiu, de rigor, de alguns membros do Ministério Público [...], instituição à qual a Constituição brasileira de 88 [...] atribuiu o papel [...] de guardião da lei e da cidadania. Ora, o perfil constitucional desenhado para o Ministério Público o foi [...] "sob a proteção de Deus", na Constituição de 88. Não deixa, portanto, de ser, no mínimo, curioso que aqueles a quem, sob a proteção de Deus, foram atribuídas as relevantes funções que hoje exercem, na sociedade brasileira, estejam a pleitear a retirada dos símbolos do divino do cenário em que atuam. É como se o Estado estivesse abolindo Deus "sob a proteção de Deus" [...] (Martins 2009b).

Outros exemplos são Nalini (2005), que relaciona diretamente a menção a Deus à formação histórica do Brasil; Nogueira (2009), que eleva a invocação divina a fundamento da "dignidade da pessoa humana"; e Costa (2009), que afirma que o fato não faz senão reconhecer a "natureza religiosa humana”.

Há muitas composições possíveis entre religião - mais especificamente, o catolicismo - e a tradição, a sociedade, a história ou a cultura - e vou utilizar apenas o último termo no que vem a seguir. ${ }^{11}$ Em certas formulações, a religião é parte da cultura; em outras, a cultura é que se torna parcela ou rebento da religião. A religião pode ainda constar como fundamento do ordenamento secular. Em todo caso, trata-se de uma entidade básica, pois mesmo quando a religião é componente, ela se introduz como capaz de sintetizar a história nacional e representar a sociedade vista como um todo. Poderíamos aplicar aqui o comentário que Ludueña (2009) elabora ao descrever como a noção de cultura aparece em textos de uma instituição que reúne o episcopado latino-americano. A cultura, nesses textos, adquire feições essencializantes, articulando certa leitura do passado à sua projeção em um futuro virtualmente eterno, justificando um estado de coisas no presente.

Sem discordar disto, penso que ainda mais importantes são as circunstâncias do uso da noção de cultura, que passa pelo que Thomas (1992) chama de objetificação - literalmente, no caso em questão, se considerarmos o argumento dos crucifixos como expressão de uma tradição cultural. Assim, uma questão mais geral seria: quais as implicações desse uso da noção de cultura, tendo em conta as possibilidades existentes na cena pública atual? Em outras palavras: por que e como 
se associa catolicismo à cultura e quais as consequências disto $?^{12}$ Outra pergunta pertinente, mais circunscrita à situação em análise, é saber se os argumentos dos opositores no debate sobre os crucifixos se utilizam da mesma noção.

É fácil perceber que não. Pelo menos foi o que constatei diante das fontes que reuni. Muito comum é a invocação de uma decisão do STF que considera o preâmbulo sem "força normativa", portanto, sem efeitos para a interpretação do art. 19 da Constituição Federal. Pinheiro (2007), além disso, tempera a leitura histórica que reconhece o papel central do catolicismo com a lembrança de dimensões que caracteriza como "dominação", "perseguição" e "hostilidades”. O mesmo faz Sottomaior (2009), que junto com Sarmento (2008) dialoga diretamente com o argumento de seus opositores. Vejamos o que escreve o último:

Não é incorreta a afirmação de que a presença de crucifixos em tribunais é tradicional no Brasil. O que é equivocada é a crença de que o papel do Direito seja o de avalizar e legitimar acriticamente as tradições existentes numa sociedade, por mais excludentes que elas sejam. [...] O caráter tradicional da prática não infirma a sua contrariedade à Constituição Federal, ou aos valores emancipatórios e democráticos que a fundamentam (:198-9).

O Direito é assim, neste caso, imbuído de uma feição “contracultural”, chamado a estender a democracia em terreno em que esta ainda não se instaurou. O deslizamento da discussão provocado pelo acionamento da noção de democracia evoca temas correlatos, sobretudo aquele da relação entre maioria e minorias. Na verdade, os defensores da presença dos crucifixos sustentam seu caráter democrático, como se verifica na sentença no caso da ACP: "O Estado laico pode ser definido como a instituição política legitimada pela soberania popular em que o poder e a autoridade das instituições do Estado vêm do povo". Em outra concepção, a democracia relaciona-se com a ideia de maioria: "Numa democracia, é a maioria que deve decidir os seus destinos. E a maioria acredita em Deus" (Martins, 2009a; também Martins, 2009b).

O argumento de Capez (2009) levanta o contraponto entre maioria e minoria:

A retirada de símbolos já instalados, mesmo que em repartições públicas, leva à alteração de uma situação já consolidada em um país composto por uma quase totalidade de adeptos da fé cristã, e agride desnecessariamente os sentimentos de milhões de brasileiros, apenas para contentar a intolerância e a supremacia da vontade de um restrito grupo de pessoas. 
A noção de minoria surge, assim, para caracterizar uma afronta à democracia: "Não é justa a opressão imposta pelas minorias religiosas à maioria católica" (Kujawski, 2007); para Martins (2009a, 2009b), seus opositores representam, com sua demanda, uma "ditadura da minoria"; ou, nas palavras de um eclesiástico, uma "minoria laicista radical” (Sales, 2009).

O registro da presença da ideia de "intolerância” no texto de Capez, assim como no de Tempesta (2009), merece destaque. Até porque há outras ocorrências:

A resposta estatal ao cidadão queixoso [...] não deveria ser uma ação civil pública, mas uma simples orientação, no sentido de que o país ter uma formação histórico-cultural cristã explica que haja na parede um crucifixo e que tal presença não importa em discriminação alguma. Ao contrário, o pensamento deletério e a ser combatido é a intolerância religiosa, que se expressa quando alguém desrespeita ou se incomoda com a opção e o sentimento religioso alheios, o que inclui querer eliminar os símbolos religiosos (Douglas, 2009).

Não é de se esquecer que o próprio conceito de Estado laico exterioriza conceito de liberdade para que as pessoas tenham suas convicções e respeitem as convicções dos outros. Eliminar a tradição de manter crucifixos nas repartições públicas - que reflete o sentimento da maioria da população - sob a alegação de que o Estado laico não permite manifestações religiosas, é, de rigor, uma forma de externar a intolerância religiosa [...] (Martins, 2009b).

O argumento da intolerância, assim articulado, permite aos defensores da presença do crucifixo uma espécie de inversão: os ofendidos não são os que não depositam alguma crença naquele objeto, mas aqueles que podem assumir essa crença diante de algum ataque.

Do lado dos defensores da retirada dos crucifixos, há o argumento que reclama que a "maioria católica" nunca se pronunciou a respeito do tema e de que boa parte da população e a própria Igreja Católica já se manifestaram a favor da laicidade ou da separação entre Estado e religião (por ex., Lorea, 2005 e petição da $\mathrm{ACP}$ ). Sobretudo, procura-se elaborar uma visão da democracia que não fique refém da vontade das maiorias e que incorpore as demandas e os direitos das minorias (Schwartzman, 2009b; Sarmento, 2008; Pinheiro, 2007; Roesler, 2010; Livianu, 2009; Farias, 2009). Destacarei trechos em que, agora desse lado da polêmica, ocorre um contraponto que acentua a proteção a que as minorias fariam jus:

Os agnósticos e ateus, assim como as minorias adeptas a todas e quaisquer religiões, têm direito de estar nesses locais sem se constrangerem com a existên- 
cia de símbolos de uma religião à qual não aderiram. Trata-se de respeitar cada brasileiro e cada brasileira no exercício pleno de suas liberdades públicas, que devem ser defendidas sempre de forma intransigente (Livianu, 2009).

A questão é aceitar que o Brasil é um país laico e que a liberdade de crença da minoria, que não se vê representada por qualquer símbolo religioso, deve ser igualmente respeitada pelo Estado (Lorea, 2005).

A presença de símbolos religiosos em repartições públicas deixa claro quem tem o poder de estabelecer os símbolos, e a quem só resta aceitar os símbolos que não lhe dizem respeito. Os símbolos religiosos afirmam hoje, como afirmavam quinhentos anos atrás, quem está mandando, e quem deve obedecer. Eles apontam que a população brasileira está dividida entre aqueles que não suportam a ideia de ter seus símbolos particulares retirados do espaço público, e aqueles que nunca tiveram seus símbolos colocados. Só poderá haver reconciliação quando nos reconhecermos como iguais (Sottomaior, 2009).

Estes trechos inspiram uma leitura que encontre na controvérsia um debate sobre representação política, a partir de configurações distintas da relação entre maioria e minorias, noções recorrentes no debate. Os defensores da permanência do crucifixo tendem a argumentar em favor da noção da maioria, o que corresponde a uma destituição política das minorias. Estas têm o direito de existir, mas devem se acomodar ("tolerar") o que seria a vontade das maiorias. Já os defensores da retirada do crucifixo têm em vista uma sociedade composta de minorias, na qual a maioria detenha um papel politicamente limitado. Esta distinção é recoberta por categorias que são semanticamente distintas: de um lado, cultura, maioria, nação; de outro, democracia, minoria, Estado. As bandeiras dos pró-crucifixos, em comparação com os de seus opositores, parecem sugerir um quadro mais orgânico e talvez imagens mais populares. Seria interessante saber como essas associações reverberam em audiências distintas, interpeladas sobre a supressão e a permanência dos objetos. Pode-se ainda notar que a noção de maioria dos pró-crucifixos é imaginária e passiva, no sentido de que não necessita de manifestação; em contraste, a noção de minoria dos anticrucifixos é virtual e ativa, no sentido de que cada manifestação (como as iniciativas de Sottomaior) demonstra e convida muitas outras, suscitadas pelo mesmo sentimento de ofensa ou constrangimento.

Ofensa e constrangimento, aliás, são invocados por ambos os lados da controvérsia. Antes de tratar disto a partir de outro ponto de vista, noto apenas uma característica curiosa dessa discussão. É que, em certo sentido, os defensores 
da permanência do crucifixo tiram da ideia de laicidade consequências que não são manifestas ou demandadas pelos defensores da retirada daquele objeto. Por exemplo, a questão dos feriados religiosos, apontados como exemplo de reconhecimento da religião pelo Estado (Ceneviva, 2005; Martins, 2009a); e a dos nomes de cidades, estados e logradouros, recorrentemente católicos (Ceneviva, 2005; Douglas, 2009). Sobretudo na repercussão do PNDH-3, foi recorrente a lembrança do monumento do Cristo Redentor, no Rio de Janeiro, como algo sob ameaça dos ideários laicistas (ver também Costa, 2009). Um modo mais simples e sutil de ampliar os alvos da laicidade é uma alteração terminológica, como faz Sales (2009) ao se referir à polêmica usando a expressão "proibição dos sinais religiosos nos espaços públicos”. Cito, por fim, a interpelação que Douglas (2009) faz ao autor da ACP:

Ao contrário do que entende o ilustre Procurador mencionado, a medida não se limitará aos ambientes de atendimento ao público. O próximo passo será proibir também os símbolos na mesa de trabalho, seja porque o ambiente pertence ao serviço público, seja porque em tese poderia ofender algum colega que visualizasse o símbolo.

Acrescentemos, portanto, essa dimensão ao debate, que opera uma possível conexão entre a laicidade - que ninguém ataca - e o laicismo - que quase sempre é evocado apenas para ser exorcizado. A diferença está no julgamento feito sobre a demanda acerca dos crucifixos, parte da agenda da laicidade - como querem os que pedem sua retirada - ou parte da agenda laicista - como querem os que pedem a sua permanência.

\section{Poderes da imagem}

Voltemos agora os olhos para esse objeto de tanta controvérsia, pois ambos os lados reconhecem nele algum tipo de agência e lhe atribuem algum poder de sedução. ${ }^{13}$ Vejamos como isto se configura no argumento dos que criticam a sua presença. Tanto Pinheiro (2009b) quanto Sarmento (2008) referem-se ao crucifixo como emissário de uma "mensagem” que age sobre os que frequentam os espaços onde se situam. Na formulação de Sarmento: "os que não pertencem à confissão religiosa favorecida recebem do Poder Público a mensagem sub-reptícia, dotada de forte carga excludente, de que as suas crenças são menos dignas de reconhecimento" (:192), “associando a prestação jurisdicional à religião majoritária” (:196). Pinheiro (2009a) dá continuidade ao argumento: "Não se deve jamais minimizar a força coercitiva e simbólica dos comportamentos do poder público”. 
Para Lorea (2005), a presença do crucifixo "chancela o controle religioso de um dos Poderes da República" e "reproduz, no plano simbólico, a aliança entre o Estado e a igreja [...] abolida com a proclamação da República". Ele prossegue: "Essa aliança não é apenas simbólica, traduz-se nas práticas do Poder Judiciário" e afigura-se como uma "postura estatal que sinaliza para toda a sociedade que o Judiciário tem premissas jurídicas calcadas em uma fé específica”. Assim, a agência do objeto atua sobre todos, julgados e julgadores, e compromete a própria Justiça. Essa agência corresponde ao polo ativo do constrangimento que seria sentido diante do crucifixo por todos aqueles que não se identificam com a fé religiosa a que se vincula. Essa agência é reforçada pelo uso de termos tais como "ostentação" e mesmo "propaganda" (Farias, 2009). Sottomaior produz o mesmo ao descrever precisamente a localização do objeto na parede, quando está acima de outros símbolos e/ ou inscrições.

Do lado dos que defendem a presença do crucifixo, temos que procurar a atribuição de agência em outras dimensões, pois, como já sinalizam as decisões nos casos do CNJ e da ACP, nega-se que esses objetos interfiram nas decisões ou constranjam os que frequentam os tribunais e outras repartições públicas. Mas não significa que não atuem sobre esses espaços. Para entendermos como isto acontece, é preciso considerar o deslizamento de sentidos atribuídos ao crucifixo. Os mesmos que reconhecem que ele é um "símbolo religioso" notam que ele é também outras coisas que emanam do primeiro significado ou que se lhe acrescentam. Vejamos como isso é articulado por Nalini (2005):

Nada mais representativo que o amor desinteressado às criaturas do que a imagem de Jesus Cristo. Entregou-se para a salvação de toda a humanidade, não apenas dos católicos. Eles nem sequer existiam quando Ele foi crucificado. Não é necessário ser crente para aceitar o heroísmo do Cristo e para nele enxergar um idealista. Virtudes desvinculadas de confissão religiosa refletem-se em sua existência histórica. Coragem, tolerância, amor desinteressado, sacrifício, doação, devotamento, desapego à matéria, oferta da própria vida não são atributos por todos prestigiados?

$\mathrm{O}$ argumento continua a afirmar a existência de dimensões que extrapolam a identidade confessional do objeto: ele "confere uma aura de respeitabilidade"; "é advertência ao operador do direito [...] de que fazer justiça é algo muito sério"; para "o desesperançado" que recorre à Justiça "pode constituir alento". E ainda, explicando por que outras confissões não se sentem agredidas: 
Em todas as religiões, a divindade é a protetora natural da moral e do direito. Deus é o Deus da justiça. Um símbolo de transcendência também contribui para o desenvolvimento de uma desejável moral civil. Quaisquer que sejam as crenças, a religião ou a falta dela, as pessoas de bem precisam de um consenso mínimo a respeito do que vale a pena em termos de conduta. A cruz pode ser alavanca para a constituição de si mesmo como sujeito moral.

Vê-se claramente como ao crucifixo é atribuída uma série de forças (respeito, advertência, alento, alavanca moral), com ação benévola sobre julgadores e julgados, independentemente de suas religiões. Trata-se de visão bastante disseminada, presente já na decisão do CNJ. Lembrança de "um dos maiores erros judiciários de todos os tempos" (Cony, 2007, repetido por Kujawski, 2007); "fontes de inspiração e [...] símbolos de um profundo chamado à ordem de que o homem foi feito para servir" (Nogueira, 2009). Martins (2009b) retoma o argumento presente na decisão no caso da ACP, fazendo o objeto anular uma divergência que outros consideram insolúvel: "De rigor, o crucifixo não representa apenas o reconhecimento da presença de Deus, para os que nele acreditam. Representa, também, para os que não acreditam, a lembrança do mais injusto julgamento da história, inspirando os magistrados a serem justos e defensores do princípio do devido processo legal [...].” Assim, para os defensores da permanência do crucifixo, a exploração de seus significados funciona tanto como exercício hermenêutico quanto como operação performática, lançando um apelo mesmo para aqueles que entendem o símbolo basicamente como um constrangimento. Vale ainda citar o artigo de Costa (2009), pois ele nos levará ao próximo ponto:

Não esqueçamos: Cristo foi a maior de todas as vítimas da injustiça humana. Sua presença simbólica lembra um erro que na qualidade de juízes não podemos cometer. Retirá-lo dos tribunais é expulsar os pobres, os oprimidos, os miseráveis, aqueles que têm fome e sede de Justiça, independente de sua raça, cor, credo ou nação. É oficializar uma Justiça elitista e curvada no altar idolátrico do grande leviatã do poder.

A evocação da idolatria sugere que há no debate dimensões que remetem ao que Latour (2002) chama de iconoclash, com seu jogo de contraposições entre iconoclastias e iconofilias. Em uma primeira aproximação, os defensores da retirada dos crucifixos das paredes de tribunais e outros estabelecimentos públicos é que ocupam a posição iconoclasta. A seguinte formulação de Sottomaior (2009) parece expressar bem o projeto generalizado desse lado da controvérsia: "Não cabe ao Es- 
tado propor a primazia de qualquer um deles sobre o outro e, no tocante à exibição de símbolos, a única maneira de fazer com que o Estado não promova nenhuma corrente acima das demais é com paredes limpas" (grifo acrescentado). Predomina, assim, a proposta de que não haja quaisquer imagens a decorar os ambientes das repartições públicas. A ideia, no entanto, convive com uma valorização dos símbolos oficialmente nacionais, o que introduz a incerteza que Latour aponta como uma das características do iconoclash. Isto aparece no mesmo texto: "As bandeiras, os hinos, os brasões, esses são símbolos que rigorosamente todos os brasileiros compartilham entre si e reconhecem como representantes de sua pátria e seu Estado" (Sottomaior, 2009). Lorea (2005) já havia proposto como solução mais adequada "preservar o espaço dos tribunais, utilizando-se somente dos símbolos da República elencados no artigo 13, primeiro parágrafo, da Constituição Federal”.

O comentário de Costa (2009) - transcrito acima - aparentemente dialogaria com essa valorização dos símbolos políticos, tida como idolátrica, pela soberba pretensão da autossuficiência de um poder com fundamento exclusivamente secular. O curioso, sem deixar de ser lógico, é que o antídoto para tal idolatria é exatamente a presença do símbolo atual. Seja como for, na verdade, o alvo da crítica dos defensores da permanência do crucifixo não é a valorização dos símbolos nacionais, mas justamente a retirada dos objetos. As indicações de Latour sobre um iconoclash nos permitem entender o que está em jogo. Depois de vermos os vários significados e agências atribuídos pelos defensores do crucifixo a este objeto, é fácil perceber: retirá-lo implica desamparar o local e seus frequentadores de um suporte necessário. Além disso, encontramos neles argumentos que sugerem que, com a retirada do crucifixo, as paredes não estariam limpas. "A decisão de não ter símbolos já é uma opção por um dos segmentos religiosos”, afirma Tempesta (2010), lamentando que o Estado queira "promover uma ideologia laicista, como se o laicismo não fosse também uma forma de religião". Concordando, Martins (2009b) teme "o endeusamento do Estado laico".

Vejamos o que afirma o texto mais articulado nessa direção (Douglas, 2009). O fato de seu autor confessar ser protestante torna-o ainda mais interessante.

Embora cristão, as doutrinas católicas diferem em muitos pontos do que eu creio, mas se foram católicos que começaram este país, me parece mais que razoável respeitar que a influência de sua fé esteja cristalizada no país. Querer extrair tais símbolos não só afronta o direito de os católicos conviverem com o legado histórico que concederam a todos, como também a história de meu próprio país e, portanto, também minha. Em certo sentido, querer sustentar que o Estado é laico para retirar os santos e Cristos crucificados não deixaria de ser uma modalidade de oportunismo. 
Continua o texto: "[...] pois tal viés ataca todos os símbolos de todas as religiões, menos uma. Sim, uma: a 'não religião', e é aqui que reside meu principal argumento contra a moda de se atacar a presença de símbolos religiosos em locais públicos”. O autor passa a caracterizar o que chama de antiteísmo, "um credo que crê que não existe Deus algum”, que tem missionários próprios, que atacam não apenas Deus, mas também os símbolos religiosos. Termina seu texto na expectativa de que os crucifixos, símbolos religiosos dos fundadores da nação e "uma salutar advertência sobre a responsabilidade dos tribunais", fiquem onde estão, pois "excluir símbolos religiosos é fazer o Estado optar por quem não crê".

Os defensores da retirada do crucifixo procuram mostrar que não estão a garantir um "Estado ateu", mas o alvo da crítica de seus opositores é o próprio ato da supressão de símbolos. Na verdade, outra solução, a da multiplicação de imagens religiosas, chega a ser imaginada pelos descontentes com o crucifixo, mas apenas como provocação ou hipótese a ser descartada. "Fosse querer reafirmar a laicidade do Estado brasileiro por esse meio, teríamos que ostentar nos prédios públicos uma incontável amostra de símbolos em alusão às diversas religiões que fazem parte da fé da população em geral, inclusive as de origem afro-brasileiras" (Roesler, 2010). Leite (2008) comenta o requerimento de um ministro do STJ (sem indicação de data) que apresentava, como alternativa à supressão do crucifixo, o acréscimo de uma torá, "símbolo da fé judaica que professo". Embora o pedido nunca tenha sido considerado, Leite toma-o como provocação para "a transformação da parede da sala da Corte em uma espécie de mural ecumênico” (:366). Realmente, a hipótese parece ter pouquíssimas chances de se realizar nos tribunais e nos parlamentos, mas aponta para outras situações, como a dos "espaços ecumênicos" em hospitais, universidades, aeroportos e outros estabelecimentos públicos e a dos monumentos religiosos - situações nas quais a multiplicação de imagens, tão central na ideia latouriana do iconoclash, torna-se a regra. ${ }^{14}$

\section{Invisibilidade exposta}

Ao lado das indicações de Latour, outra inspiração importante para minha análise da controvérsia sobre os crucifixos vem de um dos trabalhos de Taussig (1999). Nele, um dos temas centrais é o do segredo público, que envolve, na sua própria constituição, jogos de ocultação e revelação. Assim, o segredo não é aquilo que nunca pode ser descoberto, mas algo que provoca a exposição. Nesse sentido é que é público, ou familiar. Taussig está interessado em dimensões que apontam para fundamentos da sociabilidade, mas também em objetos mais específicos, como certos rituais, o tema da dádiva, as coisas sagradas. Uma operação que ganha destaque, dando título ao livro, é a da desfiguração. Para Taussig, "Quando qualquer corpo 
humano, bandeira nacional, o dinheiro, ou estátua pública é desfigurado, é como se um estranho excedente de energia negativa emergisse da própria coisa desfigurada” (:1). É a desfiguração que ativa a sacralidade que é atribuída a essas coisas, fechando o circuito que realiza o vínculo entre uma imagem e o que ela representa. Taussig (:30-1; 51-2) comenta uma observação de Robert Musil sobre os monumentos, acerca da sua invisibilidade: dispostos no meio das ruas, quase não os notamos. Trata-se, porém, de uma invisibilidade ativa, no sentido de que ela provoca uma ação que tende à desfiguração, o que por sua vez restituiria ao monumento a sua sacralidade. "Com a desfiguração, a estátua move-se de um excesso de invisibilidade para um excesso de visibilidade" (:52).

Ainda que seja, penso eu, mais adequado caracterizar a situação da controvérsia sobre crucifixos a partir do conceito de iconoclastia e seus desdobramentos, a noção de segredo público, atrelada ao jogo de ocultação e à revelação, me parece interessante para sintetizar o enfrentamento que acompanhamos, pois um dos elementos definidores dessa situação é exatamente a invisibilidade dos crucifixos. Como os monumentos na visão de Musil, os crucifixos, embora claramente expostos, não são notados pela maioria dos frequentadores dos espaços que os abrigam. Partindo disso, as demandas pela sua retirada têm necessariamente um efeito revelatório. Por outro lado, os argumentos que defendem a permanência do crucifixo são sempre reativos, ou seja, precisam ser provocados para se articularem, obrigados que são a sair, eles também, da sua invisibilidade. Tentarei mostrar que esses argumentos procuram produzir novamente uma invisibilidade para o objeto que defendem. Para tanto, gostaria de mais uma vez caracterizar os lados da controvérsia, desenvolvendo um contraponto entre os efeitos buscados pelas argumentações. Minha conclusão, em diálogo com Taussig, é que a sacralidade dos crucifixos, ao menos em uma situação na qual a desfiguração não está em jogo, depende de sua invisibilidade ativa. Em outras palavras: os crucifixos atuam melhor onde estão exatamente por não serem vistos.

Dois pontos caracterizam a denúncia levantada pelos opositores do crucifixo. Primeiro, a tentativa de imprimir à sua demanda um caráter de autoevidência. Isto não substitui os vários argumentos que são articulados, mas contribui para emprestar-lhes certo tom. Um exemplo: "Essa é uma discussão que já deveria ter sido resolvida mais de um século atrás" (Schwartzman, 2009b). A frase articula um argumento - de que a presença dos crucifixos é um resquício de um regime de relações Estado-igreja oficialmente extinto - com a sugestão de que seus opositores pertencem eles também ao passado. Outro exemplo: "Desse modo, constitui verdadeiro ‘desafio cognitivo' demonstrar que o Estado não apoia nenhuma religião particular ou em conjunto, apesar de exibir vistosamente em seus estabelecimen- 
tos abertos ao público em geral símbolos religiosos" (Farias, 2009). Neste caso, a insinuação é acerca de uma deficiência lógica que grassaria entre os defensores do crucifixo. São comuns indicações em sentido semelhante, que apontam falta de seriedade, de clareza ou de articulação nos argumentos dos defensores da presença dos símbolos religiosos. Os críticos dos crucifixos, além disso, chamam em seu apoio decisões recentes que ocorreram no exterior, nos Estados Unidos e na Europa, também acerca de símbolos religiosos em instituições públicas. Parece-me que são fatores que reforçam o caráter revelatório de suas denúncias.

Outro ponto importante, desse lado da controvérsia, é a insistência em apontar a conotação religiosa do crucifixo, em um sentido estrito, que o associa a uma confissão ou tradição específica. Os exemplos se multiplicam. "A alegação de que o crucifixo não é um símbolo religioso não é séria. Qualquer terráqueo [...] tenderá a associá-lo imediatamente ao cristianismo e à sua divindade encarnada" (Sarmento, 2008:195). "De fato, a Cruz afigura-se, desde sempre, um símbolo religioso específico da fé cristã, não podendo dissociar-se desse seu significado, o que afronta a opção constitucional pelo Estado laico que já se esperava ver consolidada” (Roesler, 2010). "[...] por mais que alguns símbolos, por sua própria aceitação, tenham se transformado em elementos distintivos da cultura e da tradição de determinado país, essa nova significação que lhes foi agregada jamais suplantará a aura religiosa que os envolve e que lhes confere sentido." (Pinheiro, 2009b). Contra o argumento de que haja na cruz um caráter ético universal, Schwartzman (2009b) reage:

Se alguém ousasse propor que as paredes de nossos tribunais fossem adornadas por forcas, guilhotinas ou cadeiras elétricas, provocaria a justa indignação de boa parte da opinião pública. Ora, nós deixamos de ver a cruz como um instrumento de execução apenas e justamente porque ela se tornou o símbolo maior do cristianismo, caráter que lhe é indissociável.

Por fim, vale citar mais um trecho, que dialoga com o argumento da cruz como lembrança do pior erro judiciário: "por que privilegiar esta injustiça particular (morte de Cristo) em detrimento de inúmeros outros absurdos jurídicos de todos os tempos?" (Vechiatti, 2008). Em suma, trata-se de evidenciar o caráter particularista do crucifixo a fim de frustrar sua pretensão de universalidade ou de nacionalidade.

Do lado dos defensores da presença do objeto, podemos caracterizar o efeito de seus argumentos com a ideia de diluição. Ela se combina com uma intenção de desmascaramento, que se aplica não sobre o objeto, mas sobre os opositores, acusados de, sabendo-o ou não, serem os arautos de um Estado espúrio ou os porta-vozes 
de uma minoria equivocada. Quanto à diluição, é como se pode descrever o que ocorre com os argumentos que incidem sobre o religioso como categoria. Neste caso, como já vimos, os defensores da presença do crucifixo procuram mostrar que o objeto tem significados e sentidos que não se restringem à sua vinculação com o cristianismo em sentido estrito. Ao mesmo tempo e por outro lado, seus argumentos enxergam o religioso entre os opositores, ou seja, entre quem se diz afastado dele. Isto ocorre quando se aponta o laicismo como uma religião, e também quando se acusa os adversários de propagandearem uma "intolerância religiosa". Parece-me que o efeito aqui caracterizado como diluição procura desestabilizar o foco produzido pelos opositores: está em outro lugar a religião que estes dizem estar condensada no crucifixo, o qual nunca é religioso no sentido em que seus críticos pensam ser.

Entre os que defendem a presença do crucifixo, podemos ainda notar o uso de expressões que traduzem o reconhecimento de um fato. Lembremos da decisão no caso da ACP que considera "natural" essa presença "em um país que teve formação histórico-cultural cristã”. Curioso é o artigo de Ceneviva (2005), pois ele não se posiciona claramente contra a retirada dos crucifixos. O texto toma como mote a proposição da moção no congresso gaúcho a fim de discutir outro tema, o dos feriados religiosos, concluindo que no Brasil "o tratamento dado a todas as religiões não é igualitário". Mas, questiona, teria que ser? Dá seu testemunho do Círio de Nazaré e as energias enormes que mobiliza. Diante disso, conclui: "Nesse assunto, alguma composição entre a lei e os fatos da vida social é necessária” (Ceneviva, 2005).

Isto se articula com a ideia recorrente de que, afinal, o assunto dos símbolos religiosos não deve ter a importância que as denúncias lhe atribuem. Assim conclui Nalini (2005) o artigo em que elenca uma série de argumentos: “O que se ganhará com a exclusão do crucifixo das salas de audiências? É nisso que residem as deficiências do Judiciário?". Outro exemplo no texto de Douglas (2009): “Tenho a esperança de que nas discussões haja mais coerência e menos "pirotecnia" e "perfumaria" de quem discute o sexo, digo, a existência dos anjos em vez de enfrentar os verdadeiros problemas de um país que, salvo raras e desonrosas exceções, é palco de feliz tolerância religiosa” (Douglas, 2009). Há, enfim, o convite que nos faz Costa (2009), que é lapidar na demonstração do que chamei de invisibilidade ativa. A parte final de seu artigo usa o crucifixo como uma metáfora que dirige o olhar para os brasileiros que estão nas prisões:

[...] meditemos em outros tipos de crucificados, estes sim que deveriam ser retirados das repartições. [...] Façamos, pois, justiça ao crucificado, Àquele que 
pagou o preço de nossa redenção há dois mil anos. Deixemo-lo onde se encontra. Jamais percamos sua lição e Graça. Quem sabe assim consigamos olhar na verdadeira direção e então ouvir os gritos dos pobres e oprimidos que estão ofegantes e cobertos de chagas à espera de autoridades justas (Costa, 2009).

Em se tratando de visibilidade, pode ser útil o contraponto com o que não deixa de ser outro crucifixo, o monumento ao Cristo Redentor, situado no cume do Corcovado, no Rio de Janeiro. Coincidentemente ou não, o monumento vem sendo tema de outras pesquisas de meu interesse (Giumbelli, 2008b; Giumbelli, 2011). É fácil constatar que a imensa popularidade do Cristo Redentor está relacionada com a multiplicação de sentidos atribuídos à imagem e de apropriações dela realizadas. A visibilidade com que se beneficia - e que foi planejada na sua construção - está portanto atrelada a essa imprevista multiplicação, que modificou sua intenção original como símbolo religioso. Por outro lado, os crucifixos em recintos públicos retiram sua agência, de acordo com os argumentos daqueles que defendem sua permanência, de sua notória invisibilidade. Embora condensem vários sentidos, esses objetos não se prestam nem a culto religioso, nem a usos de outra natureza. A invisibilidade vem acompanhada e reforçada da impossibilidade de circulação. Assim, quando alguém procura defender a presença dos crucifixos apelando para a popularidade do Cristo Redentor, sugere uma curiosa transferência: trata-se de conferir aos pequenos objetos a mesma inércia do monumento, sem abrir mão da invisibilidade que protege os primeiros e que foi determinantemente afastada no caso do segundo.

\section{Observações finais}

O tema dos crucifixos, aparentemente ausente na ocasião da posse, atrela-se a Dilma Rousseff logo depois. A reportagem de um dos maiores jornais brasileiros, ao cobrir os "primeiros dias" do mandato da nova presidente, noticia que, entre as mudanças efetivadas no seu gabinete no Palácio do Planalto, estavam a retirada da Bíblia que ficava sobre uma mesa e do crucifixo que adornava uma das paredes. A notícia não ficou sem resposta oficial, em esclarecimentos que reproduzo a seguir: "Não houve a retirada do crucifixo do gabinete presidencial. A peça pertencia ao ex-presidente Lula que a recebeu de um artista no início do governo. É de origem portuguesa"; "Ao contrário daquilo que afirmaram na mídia, não houve a retirada do exemplar da Bíblia de seu gabinete. Ela [a Bíblia] permanece na sala contígua ao gabinete, em cima de uma mesa - onde por sinal a presidente já a encontrou ao chegar ao Palácio do Planalto". ${ }^{15}$ Nota-se que o pronunciamento não se posiciona em relação à legitimidade da presença dos objetos religiosos. No caso do crucifixo, 
esse posicionamento é evitado pela caracterização do objeto como propriedade pessoal do ex-presidente, com sua origem identificada. Isto o tornava legítimo enquanto estava lá? Esta questão não é cogitada na resposta oficial e o que torna a situação interessante é que nela se realiza a retirada que, com muitos esforços, não se consegue efetivar em tribunais, parlamentos e outros recintos estatais.

O evento permite citar outros. É o caso do que ocorreu no Tribunal de Justiça do Rio de Janeiro em 2009, quando o novo presidente determinou e fez cumprir a retirada de um crucifixo de um dos auditórios, deslocando-o para um "espaço ecumênico" a ser inaugurado. ${ }^{16}$ Em 2005, um prefeito, identificado como espírita, ordenou a retirada dos símbolos religiosos nas repartições públicas no município mineiro de Ponte Nova e teria sido interessante acompanhar as reações populares à medida. ${ }^{17}$ Em 2010, o comandante do Corpo de Bombeiros de uma cidade no interior de São Paulo assinou ordem de serviço na qual manda "retirar todos os crucifixos e imagens de santos católicos das unidades sob seu comando". Em seguida, enquanto os vereadores do município repudiavam a atitude do funcionário público, uma nota atribuída à instância superior da corporação contrariou a medida, observando que "cada profissional possui a sua crença, sem a interferência da instituição". 18

Neste último caso, novamente a caracterização dos objetos como privados lhes emprestaria legitimidade. Enfim, cada uma dessas situações acrescenta aos argumentos - que pudemos acompanhar anteriormente - vários outros planos que precisariam ser abordados para se compreenderem os embates e os desfechos gerados. Seria mesmo possível imaginar movimentos de "profanação", no sentido atribuído por Howe (2009) e exemplificado pela atitude da adolescente que levou o Alcorão para o momento da prece em uma escola estadunidense nos anos 50. O caso alimentou a polêmica que culminou com a proibição, pela $\mathrm{Su}-$ prema Corte, das preces escolares.

Neste texto, meu principal objetivo esteve orientado para a compreensão dos argumentos que sustentam a presença dos crucifixos em recintos estatais diante das tentativas de minar a sua fundamentação. Espero ter demonstrado como o tema da visibilidade é crucial, como o é, em configuração inversa, para a situação recente do islã na Europa. Como argumenta Gole (2010), de várias maneiras o islã teve sua visibilidade acentuada, inclusive em controvérsias sobre vestuário e sobre arquitetura urbana. Seria possível fazer aproximações com as cenas públicas brasileiras e o modo como nelas se configuram e se distribuem imagens, objetos e monumentos, cristãos e de outras religiões? Neste texto, mantive o foco nos crucifixos que adornam locais não religiosos. Inspirando-me em Latour, Taussig e em algumas referências que trazem à baila o tema da agência das imagens, procurei demonstrar 
sob que argumentos se sustenta a invisibilidade ativa daqueles crucifixos. Devo enfim mencionar que meu exercício procura ser, dentro das regras que conformam um argumento antropológico, uma das formas de conferir evidência e de dar relevo ao objeto que discute.

Recebido em 22 de abril de 2011

Aprovado em 22 de agosto de 2011

Emerson Giumbelli é professor do Departamento de Antropologia e do Programa de Pós-Graduação em Antropologia Social da Universidade Federal do Rio Grande do Sul. Bolsista de Produtividade do CNPq. E-mail: <emerson.giumbelli@ufrgs.br> 


\section{Notas}

* Uma versão anterior deste texto foi apresentada na 27. Reunião Brasileira de Antropologia, realizada entre os dias 01 e 04 de agosto de 2010, Belém, Pará, Brasil.

1.Este texto é parte dos resultados do projeto de pesquisa "Presença Religiosa no Espaço Público no Brasil em Três Âmbitos”, desenvolvido com o apoio de Bolsa de Produtividade do CNPq. Beneficia-se das discussões ocorridas no primeiro semestre de 2009 com alguns colegas: Bernardo Freire, Christina Vital, Edilson Pereira, Izabella Bosisio, Janayna Lui, Mauro Pereira Jr. e Paola Lins. Importante também é a interlocução com Fábio Leite (2008) e o trabalho que coordena na PUC-Rio. Menciono ainda a pesquisa de César Ranquetat Jr., doutorando na UFRGS, em cujo exame de qualificação ("Laicidade à brasileira: a controvérsia sobre a presença de símbolos religiosos em espaços públicos”) pude participar. Especificamente sobre o tema, ver o artigo de Pereira Jr. (2009).

2. A descrição dos casos recentes está sistematizada em Leite (2008) e no texto apresentado por Ranquetat (2010). Sobre a ação do MP no Piauí, ver Farias (2009). O conteúdo e as reações ao PNDH-3 foram amplamente divulgados pela imprensa (p. ex., O Globo, 08/01/2010).

3. Venho reunindo material sobre o tema desde 2005. Quanto a sites jurídicos, privilegiei o Jus Navigandi, que traz, na seção "Doutrina”, vários artigos sobre o assunto. Algumas dessas referências me levaram a outras, que procurei incorporar à análise. Uma lacuna a ser registrada é o livro de Elza Galdino (Estado sem Deus: a obrigação da laicidade na Constituição, 2006), ao qual não tive acesso durante a elaboração do texto.

4. Ver www.brasilparatodos.org, acessado em 15/06/2010.

5. Disponível em http://www.prsp.mpf.gov.br/prdc/destaques/ACP\%20-\%20 simbolos\%20religiosos\%2027-07-09.pdf

6. Tive acesso ao texto do parecer graças a César Ranquetat Jr., que indica como fonte:

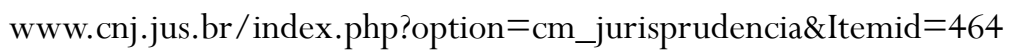

7. Tive acesso ao texto da decisão graças a César Ranquetat Jr., que indica como fonte: www.jfsp.gov.br

8. A laicidade é uma categoria que recebe o apoio de vários empreendimentos intelectuais, como demonstra o livro organizado por Lorea (2008). Em meu texto, a preocupação central é tomá-la como um elemento discursivo que precisa ser entendido analiticamente. Para a fundamentação de tal empreendimento, exercitado sobre a situação francesa, ver Giumbelli (2002).

9. A propósito do lugar, veremos que os tribunais adquirem destaque como cenário da controvérsia. Entretanto, penso que as questões levantadas podem se aplicar a qualquer recinto público estatal.

10. A questão dos signos ou símbolos religiosos, com as polêmicas que levanta acerca da relação entre religião e espaço público, ocorre em outros países, atualmente. A situação mais 
notória é a das vestimentas e adereços associados ao islã. Neste trabalho, não houve condições de contemplar o tema em outros contextos além do brasileiro.

11. Sobre este tema, ver, entre outros, Montero $(1996,2006)$.

12. Não pretendo enfrentar diretamente estas questões neste texto. Para algumas pistas, considerando o chamado campo religioso brasileiro, ver Giumbelli (2008a).

13. A inspiração vem dos trabalhos de Gell (1998), Freedberg (1989) e Mitchell (2005). O texto de Howe (2008), mais específico e voltado à discussão de um caso nos Estados Unidos que envolve um monumento aos Dez Mandamentos, também serviu de referência.

14. Nogueira (2009) inclui na discussão sobre símbolos religiosos a presença de Bíblias em prédios públicos.

15. Para a notícia, ver http://www1.folha.uol.com.br/poder/856996-biblia-ecrucifixo-sao-retirados-do-gabinete-de-dilma-no-planalto.shtml, acessado em 15/02/2011; para a nota, ver http://gazetaweb.globo.com/v2/noticias/texto_completo.php?c=221102, acessado em 15/02/2011.

16. Ver $O$ Globo, 07/02/2009.

17. Ver http: / / www.forumnow.com.br/vip/mensagens. asp?forum $=15836 \&$ topico $=2599965$, acessado em 15/06/2010.

18. Fontes: http://br.noticias.yahoo.com/s/17112010/25/manchetes-bombeiro-proibecrucifixo-causa-polemica.html e http://g1.globo.com/sao-paulo/noticia/2010/11/bombeiros-dizem-que-restricao-crucifixos-em-tatui-e-fato-isolado.html. Acessados em 01/12/2010. 


\section{Referências bibliográficas}

ASAD, Talal. 2003. Formations of the Secular: Christianity, Islam, Modernity. Stanford, CA: Stanford University Press.

BIRMAN, Patrícia (org.). 2003. Religião e Espaço Público. São Paulo: Attar/PRONEX.

CAPEZ, Fernando. 2009. "O Estado laico e a retirada de símbolos religiosos de repartições públicas”. Revista Jus Vigilantibus, setembro.

CENEVIVA. 2005. “As religiões e a constitucionalidade”. Folha de São Paulo, 15/ 10.

CONY, Carlos Heitor. 2007. "Erro judiciário”. Folha de São Paulo, 28/09.

COSTA, José Americo Abreu. 2009. "Justiça ao crucificado". Jus Navigandi, Teresina, ano 13, n. 2237, 16/08. Disponível em: http://jus2.uol.com.br/doutrina/texto.asp?id=13330. Acessado em 25/06/2010.

DOUGLAS, William. 2009. “Ação contra crucifixos mostra intolerância”. Revista Consultor Jurídico, $11 / 08$.

FARIAS, Edilsom. 2009. "Uma separação de interesse público”. Le Monde Diplomatique Brasil, setembro.

FREEDBERG, David. 1989. The Power of Images. Chicago: Chicago University Press.

GEERTZ, Clifford. 1989. "A religião como sistema cultural”. In: A Interpretação das Culturas. Rio de Janeiro: LTC.

GELL, Alfred. 1998. Art and Agency. Oxford: Oxford University Press.

GIUMBELLI, Emerson. 2002. O Fim da Religião: dilemas da liberdade religiosa no Brasil e na França. São Paulo: Attar/PRONEX.

2003. "Religião e espaço público no caso do Cristo no júri, Rio de Janeiro, 1891”. Acervo: Revista do Arquivo Nacional, Rio de Janeiro, v. 16, n. 2: 19-42.

2008a. "A Presença do Religioso no Espaço Público: Modalidades no Brasil”. Religião \& Sociedade, v. 28(2): 80-101.

2008b. "A modernidade do Cristo Redentor". Dados - Revista de Ciências Sociais, 51(1): 75-105.

2011. "Brasileiro e europeu: a construção da nacionalidade em torno do monumento ao Cristo Redentor do Corcovado". Cadernos de Antropologia e Imagem (UERJ), v. 24/1: 35-63.

GÖLE, Nilufer. 2010. "Mute symbols of Islam”. Post no site The Immanent Frame, 13/01. Disponível em: http://blogs.ssrc.org/tif/2010/01/13/mute-symbols/ Acessado em 01/02/2011 .

HOWE, Nicolas. 2009. "Secular iconoclasm: purifying, privatizing, and profaning public faith”. Social \& Cultural Geography, 10(6): 639-656. 
2008. "Thou Shalt not Misinterpret: landscape as legal performance". Annals of the Association of American Geographers, 98(2): 435-460.

KUJAWSKI, Gilberto de Mello. 2007. "Ministro Direito não pode ser discriminado como conservador". O Estado de S. Paulo. Disponível em: http://www.conjur.com.br/2007-set-13/ ministro_nao_discriminado_conservador. Acessado em 25/06/2010.

LATOUR, Bruno. 2002. "Introduction”. In: Iconoclash. Beyond the image wars in science, religion and art. Karlsruhe: MIT Press \& ZKM.

LEITE, Fábio Carvalho. 2008. Estado e religião no Brasil: a liberdade religiosa na Constituição de 1988. Tese de Doutorado, Programa de Pós-Graduação em Direito, Universidade do Estado do Rio de Janeiro.

LIVIANU, Roberto. 2009. "Sagrada Laicidade”. Folha de São Paulo, 07/08.

LOREA, Roberto (org.). 2008. Em defesa das liberdades laicas. Porto Alegre: Livraria do Advogado.

. 2005. “O Poder Judiciário é laico”. Folha de São Paulo, 24/09.

LUDUEÑA, Gustavo Andrés. 2009. "La cultura católica en la imaginación política de las iglesias latinoamericanas”. In: Martín Steil \& Camurça (orgs.). Religiones y Culturas. Perspectivas Latinoamericanas. Buenos Aires: Biblos.

MARTINS, Ives Gandra. 2009a. “A ditadura do laicismo”. Folha de São Paulo, 07/11. 2009b. "O endeusamento do Estado laico", Jornal do Brasil, 12/8.

MITCHELL, W.T.J. 2005. What do PicturesWant. Chicago: University of Chicago Press.

MONTERO, P. (org.). 1996. Entre o mito e a história. As comemorações em torno doV Centenário do Descobrimento da América. Petrópolis: Vozes.

(org). 2006. Deus na Aldeia:Missionários, Índios e Mediação Cultural. São Paulo: Globo.

NALINI, José Renato. 2005. “A cruz e a Justiça”. Folha de São Paulo, 24/09.

NOGUEIRA, Rober to Wagner Lima. 2009. “O uso de crucifixos e bíblias em prédios públicos à luz da Constituição Federal”. Jus Navigandi, Teresina, ano 13, n. 2123, 24/04. Disponível em: <http: / /jus2.uol.com.br/doutrina/texto.asp?id=12686>. Acessado em 25/06/2010

PEREIRA Jr., Mauro. 2009. “O crucifixo no tribunal do júri: sobre Estado e religião no Brasil”. Revista Habitus: revista eletrônica dos alunos de graduação em Ciências Sociais - IFCS/UFRJ, Rio de Janeiro, v. 7, n. 1: 1-16, julho. Disponível em: <www.habitus.ifcs.ufrj.br $>$. Acessado em $25 / 06 / 2010$

PINHEIRO, Maria Cláudia Bucchianeri. 2007. "O Conselho Nacional de Justiça e a permissibilidade da aposição de símbolos religiosos em fóruns e tribunais: uma decisão viola a cláusula da separação Estado-Igreja e que esvazia o conteúdo do princípio constitucional da liberdade religiosa”. Jus Navigandi, Teresina, ano 11, n. 1457, 28/06. Disponível em: <http://jus2.uol. com.br/doutrina/texto.asp?id=10039>. Acessado em 25/06/2010 
. 2009a. "O Estado e os crucifixos". O Globo, 28/02.

2009b. “A condenação da Itália pela Corte Europeia de Direitos Humanos, por ostentar crucifixos em escolas públicas. Uma lição ao Brasil”. Jus Navigandi, Teresina, ano 14, n. 2326, 13/11. Disponível em: http://jus2.uol.com.br/doutrina/texto.asp?id=13844. Acessado em 25/06/2010

QUEIROZ, Fernando Fonseca de. 2006. "Brasil: Estado laico e a inconstitucionalidade da existência de símbolos religiosos em prédios públicos”. Jus Navigandi, Teresina, ano 10, n. 1081, 17/06. Disponível em: <http://jus2.uol.com.br/doutrina/texto.asp?id=8519>. Acessado em 25/06/2010

RANQUETAT JUNIOR, César. 2010. "Laicidade à brasileira: a controvérsia sobre a presença de símbolos religiosos em espaços públicos”. Texto apresentado para obtenção de qualificação em doutorado, Programa de Pós-Graduação em Antropologia Social, Universidade Federal do Rio Grande do Sul.

ROESLER, Átila Da Rold. 2010. “O Estado não tem o direito de ostentar símbolos religiosos”. Jus Navigandi, Teresina, ano 14, n. 2401, 27/01. Disponível em: http://jus2.uol.com. $\mathrm{br} /$ doutrina/texto.asp?id=14252. Acessado em 25/06/2010

SALES, Eugênio. 200 9. "Minoria laicista radical”. O Globo, 28/03.

SARMENTO, Daniel. 2008. "O crucifixo nos Tribunais e a laicidade do Estado". In: Roberto Lorea (org.). Em defesa das liberdades laicas. Porto Alegre: Livraria do Advogado.

SCHWARTZMAN, Hélio. "Crucifixos na berlinda". 2009a. Folha Online, 13/08. Disponível em: http://www1.folha.uol.com.br/folha/pensata/helioschwartsman/ult510u608704. shtml. Acessado em 14/08/2009.

. 2009b. "França detém vanguarda da laicidade". Folha de São Paulo, 05 / 08.

SOTTOMAIOR, Daniel. 2009. "O Estado verdadeiramente laico e a retirada de símbolos religiosos de repartição pública”. Jus Navigandi, Teresina, ano 13, n. 2260, 08/09. Disponível em: http: / /jus2.uol.com.br/doutrina/texto.asp?id=13465. Acessado em 25/06/2010

TAUSSIG, Michael. 1999. Defacement. Stanford: Stanford University Press.

TEMPESTA, Orani João. 2009. “A propósito do Acordo”. O Testemunho de Fé, 30/08. . 2010. “A intolerância anunciada”. O Globo, 15/01.

THOMAS, Nicholas. 1992. “The inversion of tradition”. American Ethnologist, 19(2): 213-232.

VECCHIATTI, Paulo Roberto Iotti. 2008. "Laicidade Estatal tomada a sério”. Jus Navigandi, Teresina, ano 12, n. 1830, 5/07. Disponível em: <http://jus2.uol.com.br/doutrina/texto. asp?id $=11463>$. Acessado em 25/06/2010 


\section{Resumo}

O trabalho reúne, sistematiza e analisa os argumentos que se embatem em polêmicas recentes no Brasil acerca da presença de crucifixos em recintos públicos (tribunais, parlamentos etc.). Concepções de laici-dade e poderes da imagem são temas que ressaltam posições contra e a favor da permanência daqueles objetos. Procura-se demonstrar que a lógica da presença dos crucifixos depende de uma invisibilidade ativa.

Palavras-chave: símbolos religiosos, laicidade, imagem

\section{Abstract}

The article compiles, systematizes and analyzes the recent controversies about the presence of crucifixes in public places (courts, parliaments etc.) in Brazil. Conceptions of secularism and powers of the image are issues that structure positions for and against the permanence of those objects. The argument seeks to show that the logic of the presence of crucifixes depends on an active invisibility.

Keywords: religious symbols, secularism, image 